\title{
Variations in Hydraulic Properties of Sendimentary Rocks Induced by Fluid Injection: The Effect of Water Pressure
}

\author{
Zhen Huangi-3*, Xiaozhao Li ${ }^{1}$, Shijie $\mathrm{Li}^{2}$, Kui Zhao², Hongwei Xu² \\ ${ }^{1}$ School of Earth Sciences and Engineering, Nanjing University, Nanjing, China \\ ${ }^{2}$ School of Resources and Environment Engineering, Jiangxi University of Science and Technology, \\ Ganzhou, Jiangxi, China \\ ${ }^{3}$ State Key Laboratory for GeoMechanics and Deep Underground Engineering, \\ China University of Mining and Technology, Xuzhou, Jiangsu, China
}

Received: 3 January 2018

Accepted: 11 February 2018

\begin{abstract}
Water inrush during the excavation of mines or mining is one of the great challenges in underground engineering work in China. To prevent and/or mitigate water inrush, natural sedimentary rocks with low-permeability, which include the mudstone and sandstone found in underground excavations, are exceptional materials for geological barriers. The aim of this work is to therefore investigate the hydraulic properties of sedimentary rocks in a deep tunnel, with the application of high-pressure packer tests (HPPTs). The experimental results indicate that both the mudstone and sandstone are low permeability. The measured injection pressure-flow rate $(P-Q)$ can be divided into two phases: Phase I - a flow that is Darcian with a linear relationship, and Phase II - changes in the flow pattern with an exponential relationship. Water injection primarily triggers fracture dilation, and then results in an evident increase in hydraulic conductivity. The hydraulic conductivity versus water pressure distribution phase can be considered as three flow phases: the initial flow phase, initiation of flow communication phase, and non-steady state flow phase. The calculated original fracture apertures in mudstone and sandstone are, respectively, 0.37 and $0.33 \mathrm{~mm}$. Furthermore, a conceptual model with two phases of fracture aperture versus water pressure is proposed.
\end{abstract}

Keywords: water inrush, sedimentary rock, hydraulic conductivity, hydraulic test, hydraulic fracturing

\section{Introduction}

Currently, China is the world's largest coal producer [1]. Although China has restricted its coal output in

*e-mail: huangzhen075@163.com recent years, the economy of China will still be highly dependent on coal extraction and production in the foreseeable future [2]. However, groundwater inrush into the mine working face is a common occurrence during the extraction of this important resource [2-5], which is one of the greatest challenges in underground engineering [5-13]. Statistics for the past 20 years in China show that 


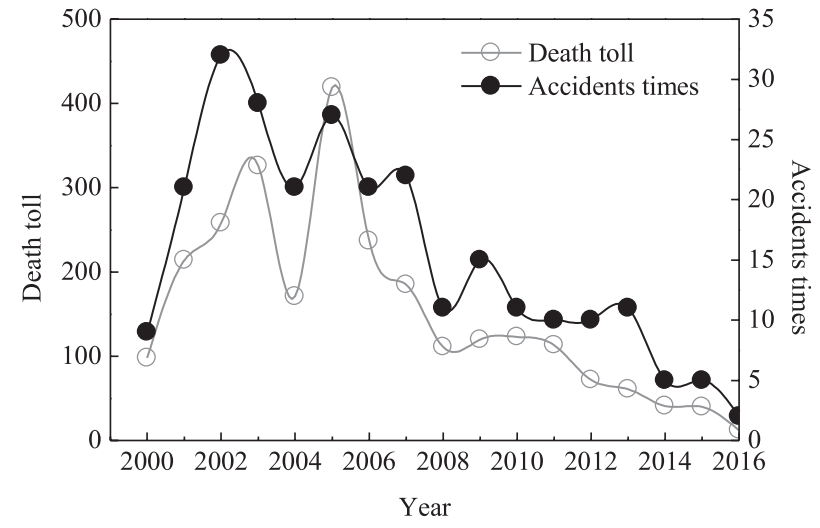

Fig. 1. Severe mine water inrush accidents in China from 2000 to 2016 .

inrushes have occurred in more than 250 coal mines and have resulted in more than 2,000 casualties. Even though the number of water inrush events and deaths have been declining since 2005 (Fig. 1) [4], the immense danger posed by inrushes cannot be neglected because they cause serious loss of human life and are financially detrimental (Fig. 2). In addition, groundwater inrushes also pollute the environment [2, 14-15]. Therefore, field and laboratory investigations that predict and examine water inrush [16-18], and the effects of groundwater inrush on the hydraulic and mechanical properties of rock masses [17, 19-21], have been extensively carried out.

Natural sedimentary rocks that are found in underground excavations are considered to be a good candidate for waterproofing coal mines as they have low permeability. The rapid development of the coal industry in China in the past decade means that significant exploitation of coal seams in deep mines has taken place [22]. As a result, the risk of water inrush is increased due to the complex geological conditions (e.g., subject to geostatic stress, high water pressure, and high temperatures) [22]. Therefore, there is practical importance for studying the hydraulic properties of

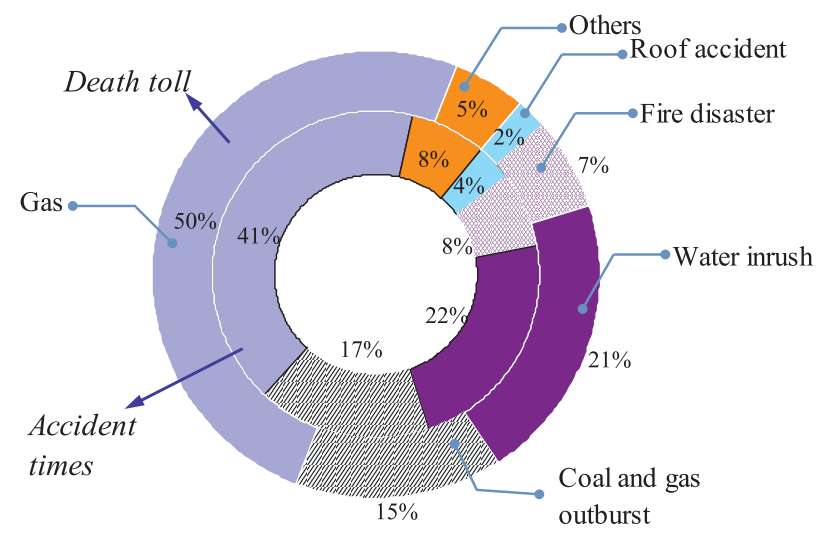

Fig. 2. Types of severe geological disasters in coal mines and their percentages from 2005 to 2014 in China. sedimentary rocks that are subjected to high water pressure. In-situ hydraulic tests, such as conventional hydraulic tests (CHTs) and high-pressure packer tests (HPPTs), are commonly used to measure the hydraulic properties of rocks [23-25]. However, CHTs may not apply to extremely low permeable rocks or when pressure sensitivity of permeability is an issue. These limitations can be addressed by using modified HPPTs [25]. Thus, there has been an increasing emergence of using HPPTs as an alternative to CHTs for evaluating the hydraulic properties of rocks in water resources and hydraulic engineering, but they have been less frequently used to examine natural sedimentary rocks in coal seam floors of deep mines. Therefore, the hydraulic properties of sedimentary rocks found at a depth of about 650-800 m in a test site in the Dongtan Mine, Jining City, Shangdong Province in China, are determined through HPPTs, and equations that show the evolution of rock permeability and fracture dilation when subjected to water pressure are provided.

\section{Experimental Details}

The test site is located in Dongtan Mine, Jining City, Shandong Province in China (Fig. 3a), where there are plans for mining coal seams at greater depths. Two types of natural rocks, i.e., mudstone and sandstone, found at a depth of 650 to $800 \mathrm{~m}$ and initially undisturbed were examined through high-pressure packer testing with high-pressure injections of water (Fig. 3b) for determining the in-situ hydraulic properties [26]. Table 1 shows the physical and mechanical properties of the test sections. The equipment for the high-pressure packer testing consisted of a down hole injector for carrying out the injection and an aboveground instrument for monitoring the process and recording the data [25-27]. Water was injected into the rock between two inflatable packers that spanned the test site. Details on the procedures of high-pressure packer testing have been provided in the literature (see Chen et al. [25]). The HPPTs in our work were conducted with a stepwise increase $(0.5-2.5 \mathrm{MPa})$ of the injection pressure until a maximum injection pressure of approximately $13 \mathrm{MPa}$ , and then the injection pressure was kept constant until the flow rate reached a steady or quasi-steady

Table 1. Physical and mechanical properties of the test sections.

\begin{tabular}{|c|c|c|}
\hline Information & $\begin{array}{c}\text { First test } \\
\text { section }\end{array}$ & $\begin{array}{c}\text { Second test } \\
\text { section }\end{array}$ \\
\hline Lithology & Mudstone & Sandstone \\
\hline Compressive strength $(\mathrm{MPa})$ & $18.0 \sim 36.9$ & $79.6 \sim 89.0$ \\
\hline Tensile strength $(\mathrm{MPa})$ & $1.2 \sim 3.0$ & $7.7 \sim 9.8$ \\
\hline Poisson ratio & $0.22 \sim 0.29$ & $0.19 \sim 0.23$ \\
\hline Elastic modulus $(\mathrm{GPa})$ & $3.9 \sim 8.2$ & $16.0 \sim 24.7$ \\
\hline
\end{tabular}




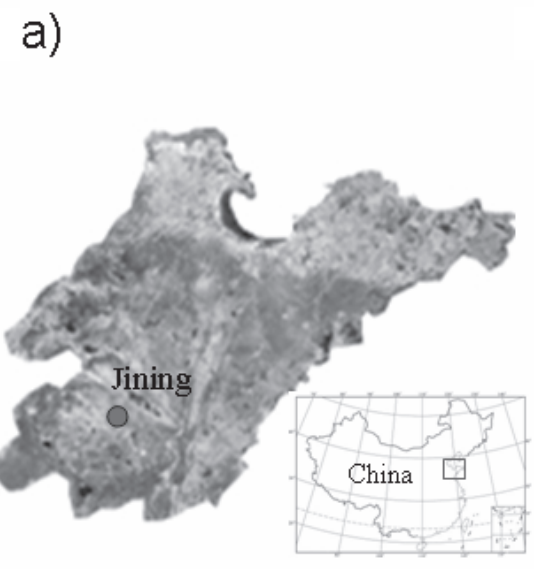

b)

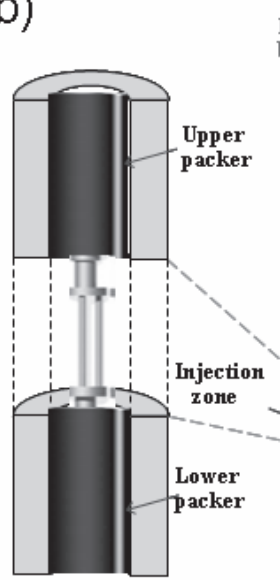

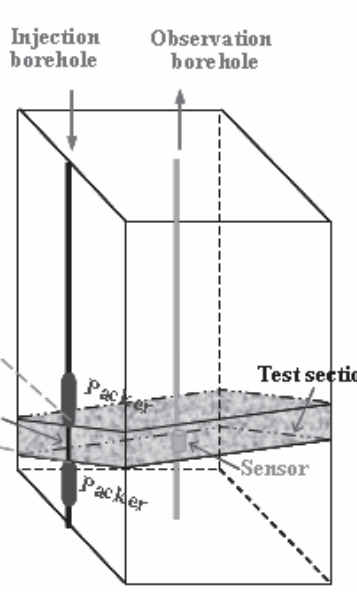

c)
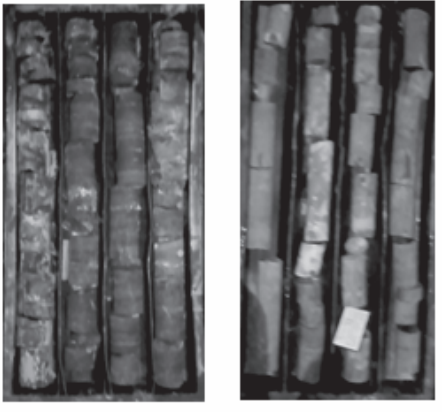

$-691.5 \sim-695.5 \mathrm{~m}$

$-756.1 \sim-760.3 \mathrm{~m}$

Fig. 3. Experiment setting of the HPPT: a) location of the tested area, b) schematic diagram of the HPPT method, and c) the cores forming the injection zone.

state. Water was injected into the rock samples and the injection pressure $(P)$, observed pressure $(p)$, and flow rate $(Q)$ were measured.

The rock samples that were originally drilled from the test site were petrographically analyzed using x-ray diffraction (XRD) and scanning electron microscopy (SEM). The clay $(<2 \mu \mathrm{m})$ layers have $55 \%$ kaolinite, $39 \%$ illite, and a mixed mineral composition of $4 \%$ illite/montmorillonite; the mudstone layers have $1 \%$ montmorillonite and $1 \%$ chlorite; and the sandstone layers have $57 \%$ kaolinite, $36 \%$ illite, a mixed mineral composition of $4 \%$ illite/montmorillonite, $1 \%$ montmorillonite, and $2 \%$ chlorite. They have low porosities of $1.8 \%$ to $6.4 \%$, which leads to low permeability.

\section{Results and Discussion}

\section{Hydraulic Conductivity of Rocks Subjected to High Water Pressure}

Table 2 shows the results of the two different approaches for testing used in this study, i.e., single borehole (Eq. 1) and cross-hole (Eq. 2) testing, to determine the hydraulic conductivity $(k)$ of fractured geological media based on in-situ hydraulic tests. Both approaches assume a steady-state laminar flow in the homogeneous and isotropic media around the boreholes. Single borehole testing has been used for many years to determine the distribution of permeability along boreholes [24, 28-30], and Eq. 1 is the commonly applied equation:

$$
k=\frac{Q}{2 \pi L H_{0}} \ln \left(L / r_{w}\right)
$$

...where $k$ is hydraulic conductivity, $Q$ is the flow rate, $L$ is the length of the tested section, $H_{0}$ is the water head difference, and $r_{w}$ is the diameter of the borehole.

Compared with a single borehole test, the cross-bore test is carried out by drilling one injection or pumped borehole and one observation borehole [4, 20, 31-33]. For the second approach, hydraulic conductivity can be calculated using the data collected from the two boreholes. In this study, during each step of HPPTs, $Q$ is an assumed constant and $P$ is kept constant, the hydraulic conductivity $k$ is then deduced from Darcy's Law and Dupuit's equation $[4,20,33]$ :

$$
k=\frac{Q(\ln R-\ln r)}{2 \pi L\left(H_{P_{0}}-H_{P_{t}}\right)}
$$

...where $k$ is hydraulic conductivity, $Q$ is the flow rate, $R$ is the distance from the injection borehole to the observation borehole, $r$ is the diameter of the borehole, and $H_{P O}$ and $H_{P t}$ are the head in the injection and observation boreholes, respectively. In this study, hydraulic conductivity was estimated using Eq. 2.

Fig. 4a) shows the changes in water pressure ( $P$ and $p$ ), flow rate $(Q)$, and hydraulic conductivity $(k)$ with time during the injection, which proceeded for $250 \mathrm{~min}$. As can be observed, $p$ and $k$ are initially constant in the mudstone and sandstone for the first injection and then increase slightly after about 26 and 15 min (Point $\mathrm{S}_{0}$ in Fig. 4), respectively, and then significantly increased at an injection pressure of about 11.32 and $8.98 \mathrm{MPa}$ (Point $\mathrm{S}_{\mathrm{s}}$ in Fig. 4), respectively. The results indicate that the communication of water flow is initiated at $\mathrm{S}_{0}$ and hydraulic fracturing at $\mathrm{S}_{\mathrm{s}}$. The relationship between the hydraulic conductivity $(k)$ and injection pressure $(P)$ is shown in Fig. 4b), in which the trend of change in the $k$ - $P$ curves is basically the same. No apparent increases in hydraulic conductivity can be detected until $P$ reaches the threshold pressure, which is about 162 and $60 \mathrm{~min}$ into the experiment for the mudstone and sandstone, 
Table 2. Overview of the mathematical model for hydraulic conductivity calculation.

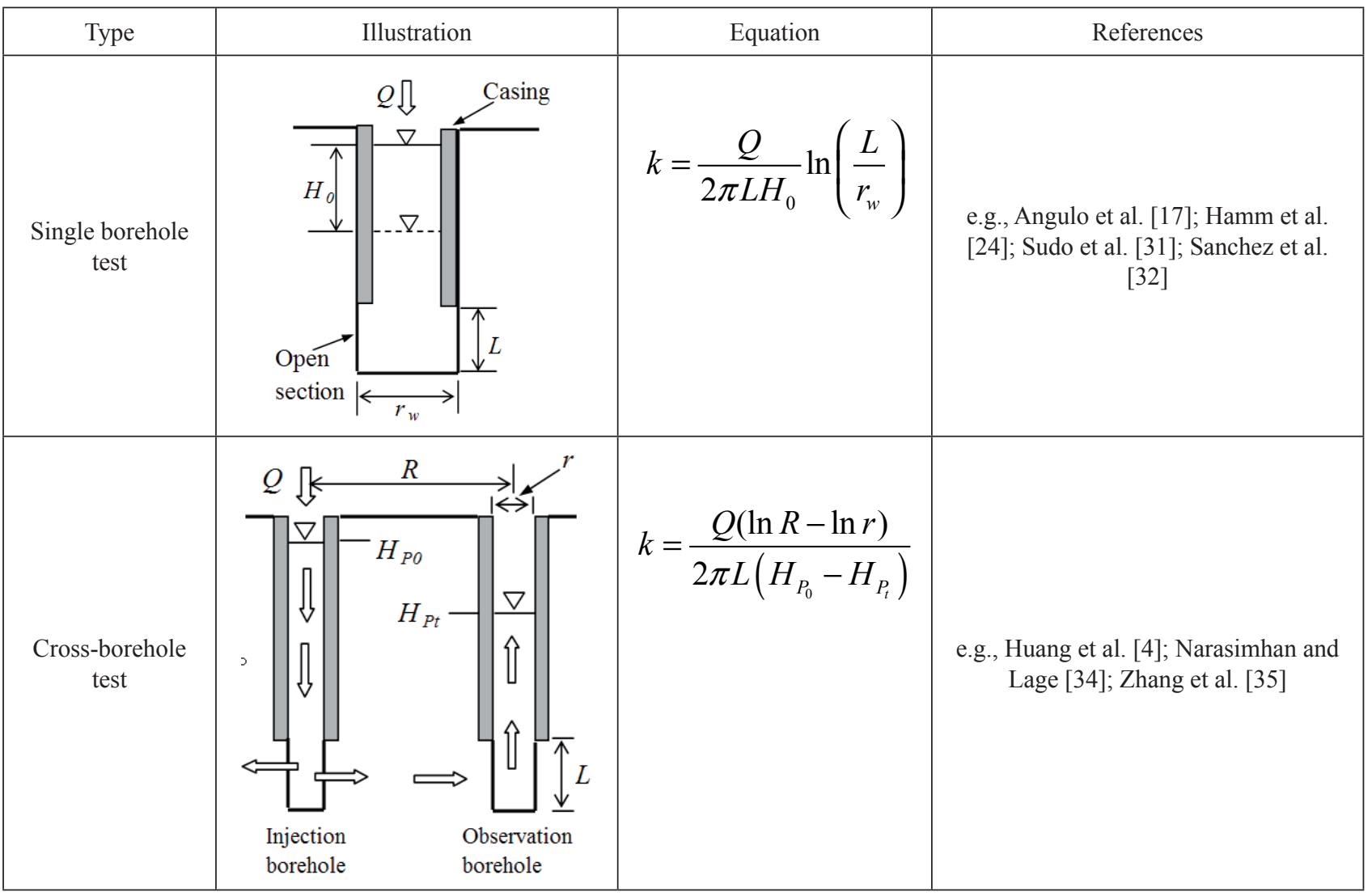

a)
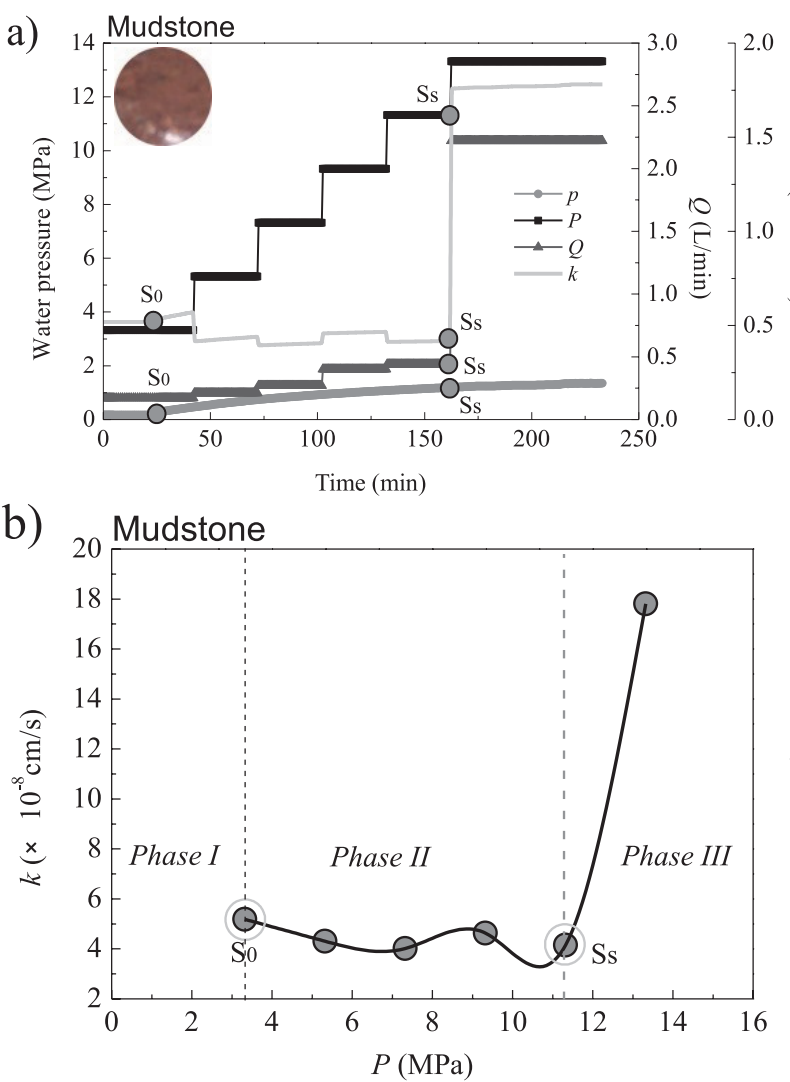
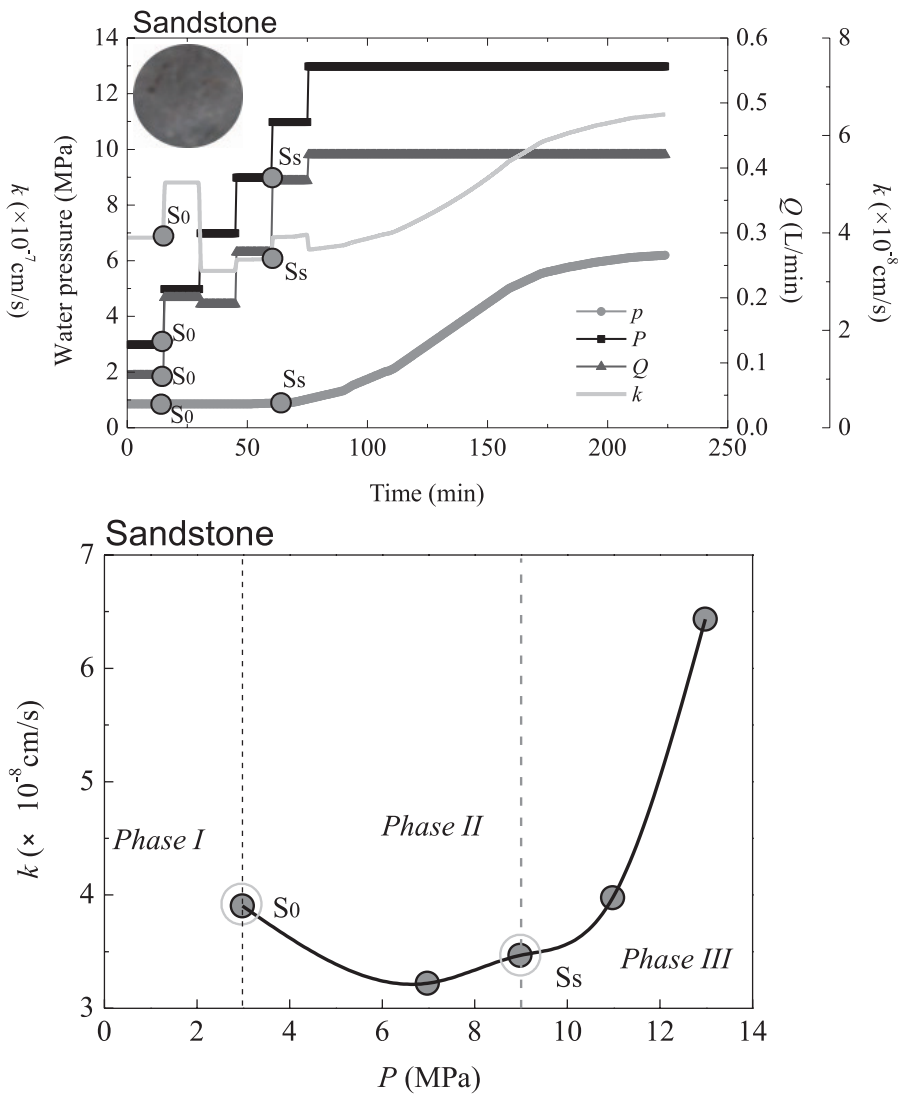

Fig. 4. a) Water pressure $(P, p)$, flow rate $(Q)$, and estimation of rock permeability $(k)$ induced over time by water injection;(b) hydraulic conductivity $(k)$ versus injection pressure $(P)$. 
respectively. The results show about a 4-fold increase in the hydraulic conductivity of the mudstone from 4.1 to $17.7 \times 10^{-8} \mathrm{~cm} / \mathrm{s}$ and a 2-fold increase in the hydraulic conductivity of the sandstone from 3.2 to $6.4 \times 10^{-8} \mathrm{~cm} / \mathrm{s}$ during the water injection. These increases in hydraulic conductivity are probably the result of the opening of fractures within the rocks under high injection pressure. When the measurements from the HPPTs and corresponding changes in hydraulic conductivity are examined, they reveal three flow phases. Phase I is defined here as the initial flow phase, and takes place in the early stages of high-pressure packer testing, wherein no notable pressure variations can be detected in the observation borehole, and $k$ is the initial hydraulic conductivity. Phase II is the initiation of flow communication phase in which the injected water flows to the observation borehole through the pores and fractures within the rock [20], and $k$ is somewhat changed. Phase III is defined as the non-steady-state flow phase, wherein further increases in the injection pressure result in initiation of new fractures and propagation of old fractures within the rock, and consequently $k$ is increased due to significant fracture dilation and hydraulic fracturing $[20,25,34]$.

\section{Relationship between Flow Rate and Injection Pressure}

Characterization of the injection pressure-flow rate $(P-Q)$ plots obtained from the HPPTs plays an important role in understanding the flow behavior in rocks under increasing injection pressure [25]. Quinn et al. [35-36] discussed the relationship between the flow rate and applied head in the borehole, which was used to identify the flow regime. In a flow that is Darcian, $Q / P$ is a constant (or the inverse, $P / Q$ is a constant), i.e., the Darcy flow is a linear relationship between flow rate and pressure. Numerical analyses carried out by Rutqvist [37] on injection tests showed that the flow rate at each pressure step is strongly dependent on the fracture aperture and normal stiffness near the borehole, which has the highest flow resistance and pressure gradient. In addition, in the pressure versus flow rate response from a hydraulic test carried out in southeastern Sweden on Laxemar crystalline rock, the flow rate increased as a nonlinear function of pressure [37]. Fig. 5 shows the relationship between the flow rate and the injection pressure from the HPPTs in this study. It can be seen that the flow rate increases linearly with pressure until the fracturing threshold has been exceeded. The reasons for the non-linearity have been provided by many researchers $[25,35-37]$. The results of this study are in agreement with Quinn et al. [35-36], in that the non-linearity is caused by a high injection pressure, i.e., the critical pressure that causes fracture dilation and/or hydraulic fracturing. Nonetheless, as shown in Fig. 5, the initial and partial transitional flow of HPPTs still retain a linear relationship between $Q$ and $P$, which is a flow that is
Darcian [38]. Thus, the initial hydraulic conductivity can be calculated using Darcy's law.

Furthermore, the $Q-P$ relationship can be used to investigate the hydraulic conductivity of the tested sections [25, 39-41]. Fracture dilation and hydraulic fracturing can change flow patterns, which is the critical state. The $P-Q$ curves (Fig. 5) show the phase characteristics which can be approximately divided into two phases. In Phase I (i.e., $Q<Q_{c} \approx 0.44 \mathrm{~L} / \mathrm{min}$ in Fig. 5a) and $Q<Q_{c} \approx 0.19 \mathrm{~L} / \mathrm{min}$ in Fig. 5b), the flow rate $(Q)$ is approximately linearly proportional to the injection pressure $(P)$ with high regression coefficients $\left(R^{2}=0.98\right.$ and 0.89 , respectively), which indicates that the hydraulic conductivity of the rock masses can be approximated with a constant and the flow in the rocks is Darcian $[4,25]$. Thus, the calculated hydraulic conductivity in this phase can be considered as the initial hydraulic conductivity of the tested sections. In Phase II, as the injection pressure increases up to the critical pressure $\left(P_{c}\right)$, significant fracture dilation and hydraulic fracturing occur in the rocks between the injection and observed boreholes [25]. Darcy's law breaks down and the $P-Q$ curves show non-linearity, thus indicating flow regime variation during the injection, i.e., changing from
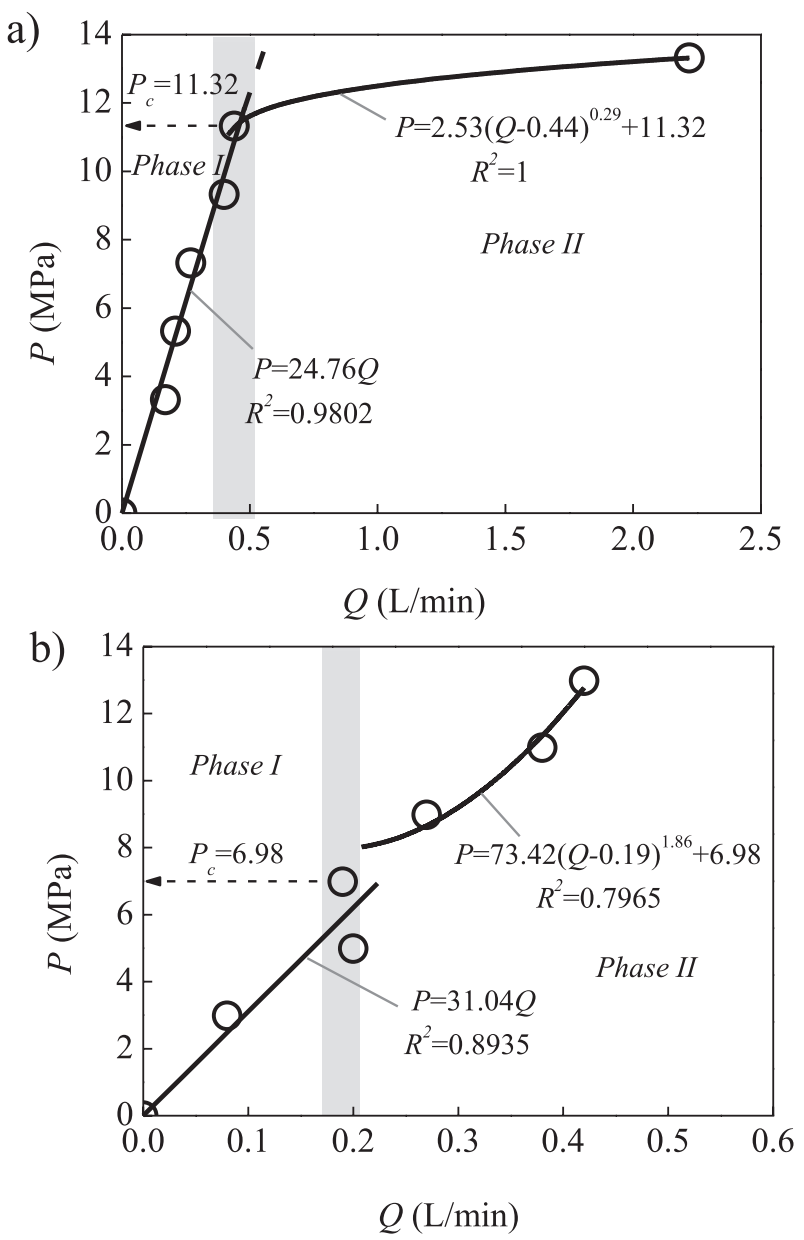

Fig. 5. Relationship between flow rate $(Q)$ and injection pressure $(P)$; a) mudstone and b) sandstone. 
a Darcy flow to a non-Darcy flow. As shown in Fig. 5, the $P-Q$ curves in Phase II can be adequately approximated with the following function in which $R^{2}=1$ and 0.80 , respectively:

$$
P=\alpha\left(Q-Q_{c}\right)^{\beta}+P_{c}
$$

...where $\alpha$ and $\beta$ are the fitting coefficients, $P_{c}$ is the critical pressure that initiates the hydraulic fracturing, and $Q_{c}$ is the corresponding flow rate. The results show that the values of $P_{c}$ are 11.32 and $6.98 \mathrm{MPa}$ for the mudstone and sandstone, respectively

\section{Fracture Dilation Characterization}

Hydraulic apertures are an important means for studying the hydraulic properties of rocks [41-42]. Apertures or fractures are the primary channels for groundwater flow in rock masses [5, 43-45]. As a result of the opening, the growth and propagation of fractures in rock masses are caused by excavation and high water pressure [25], water channels from inrush form, and there is the flooding of groundwater into the excavated areas. It is well known that fracture apertures are the key parameter for characterizing flow in fractured rock media [46]. However, determining the distribution of fracture apertures is an extremely difficult task because

a)

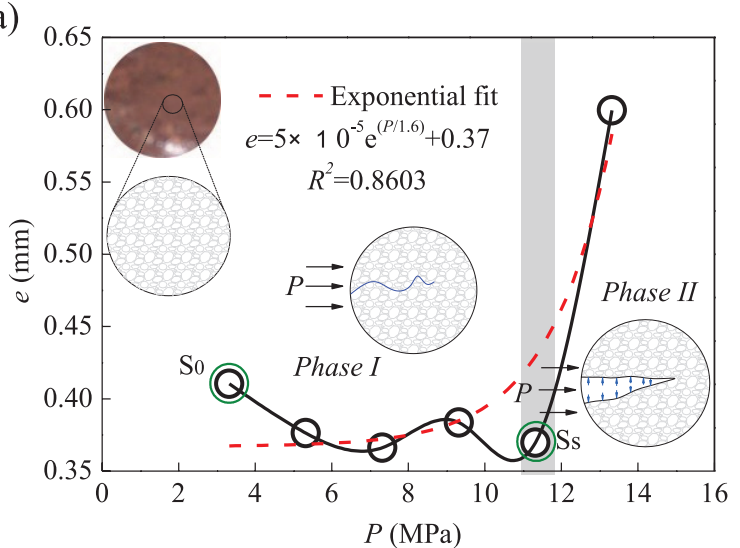

b)

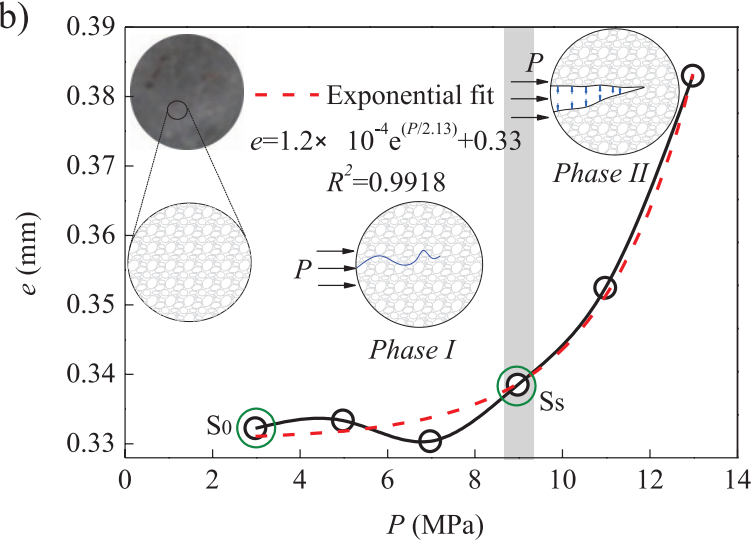

Fig. 6. Fracture propagation behaviors induced by water injection. natural fractures are generally rough and irregular with uneven surfaces, which usually make contact at several discrete points [46]. Therefore, the properties of a simple fracture are usually studied through laboratory experiments [38, 47-49] and numerical simulations [46, 49-50]. Despite extensive studies by numerous researchers on flow through fractures, there is still no universal consensus on a quantitative relationship between fracture permeability and fracture apertures [46].

Nevertheless, the well-known "cubic law" has been proposed, which assumes that flow through two parallel plates is confined between the plates [40]:

$$
Q=\frac{g e^{3} i}{12 \mu}
$$

...where $Q$ is the flow rate, $e$ is the fracture aperture, $i$ is a dimensionless hydraulic gradient, $\mu$ is the dynamic viscosity of the fluid, and $g$ is acceleration due to gravity.

The fracture aperture (e) can be deduced with the "cubic law" [38]:

$$
e=\left(\frac{Q}{i} \frac{12 \mu}{g}\right)^{1 / 3}
$$

However, the classical cubic law generally overestimates flow through real fractures and does not take into account local tortuosity and roughness [51].

a)
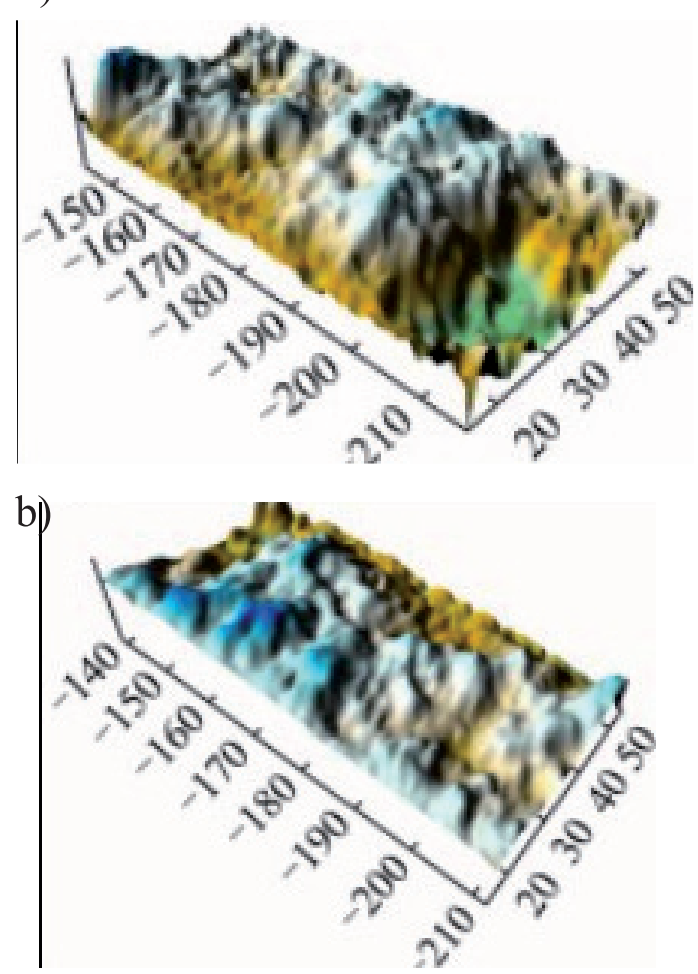

Fig. 7. 3D topographies of fracture surfaces a) before and b) after water washing (Yang et al. 2013). 


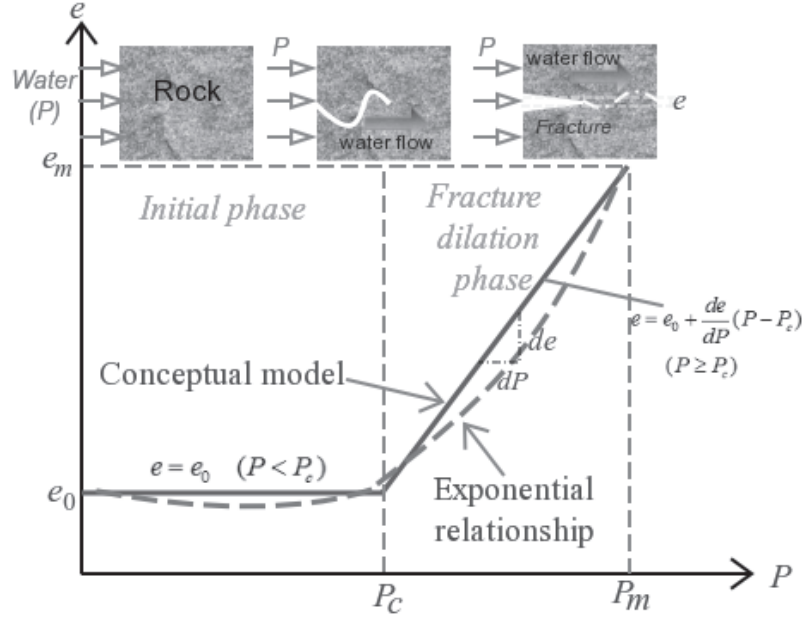

Fig. 8. A conceptual model of fracture aperture $(e)$ versus water pressure $(P)$.

Hence, the classical cubic law may be not fit the actual condition well. However, due to the complex factors, matching the cross-hole testing data with an accurate model that incorporates flow path geometry and hydraulic properties is unlikely to have neither a simple nor a unique solution. We therefore used Eq. 5 to calculate the fracture aperture (e).

The results in Fig. 6 show the calculated fracture aperture (e) from the experimental data by using Eq. 5 . The fitting results show that an exponential relationship is found between $P$ and $e$, with high regression coefficients $\left(R^{2}=0.86\right.$ and 0.99 , respectively). Fig. 6 also demonstrates the gradual evolution of fracture apertures in rocks during water injection and can be divided into two phases based on the critical point, which agrees well with flow behaviors:

(1) Phase I (initial flow phase and initiation of flow communication phase), which occurs in the early stages of a hydraulic test, in which $Q$ increases linearly with $P$ [25], and $e$ is approximately constant and considered as the original fracture aperture:

$$
e=e_{0} \quad\left(P<P_{c}\right)
$$

...where $e_{0}$ is the original fracture aperture of the rocks, and $e_{0} \approx 0.37$ and $0.33 \mathrm{~mm}$ for the mudstone and sandstone, respectively, and $P_{c}$ is the critical pressure that corresponds to the initiation of hydraulic fracturing. In this phase, water flows from the injection to the observation boreholes through the original pores and fractures.

(2) Phase II (non-steady-state flow phase or hydraulic dilation) describes the hydraulic dilation that takes place after the critical point, and fracture aperture (e) increases because of the formation of new fractures due to hydraulic fracturing. In this phase, the water pressure is higher than the critical pressure $\left(P_{c}\right)$, which could lead to hydraulic fracturing, and will contribute to the development of flow channels, i.e., the formation of a fracture network. Moreover, high-pressure water flow can result in the widening and interconnecting of fractures (Fig. 7), and the hydro-mechanical properties are mainly affected by the complex morphological characteristics of fracture surfaces [52]. As a result, significant changes in the hydraulic properties will take place in this phase, which is noteworthy. Fracture aperture $(e)$ versus water pressure $(P)$ in Phase II can be simplified as a linear relationship to make the calculation convenient. Then, the $e-P$ curves in this phase can be adequately approximated with the following function:

$$
e=e_{0}+\frac{d e}{d P}\left(P-P_{c}\right) \quad\left(P \geq P_{c}\right)
$$

\section{... where $\frac{d e}{d P}$ is the proportionality coefficient.}

A conceptual model of fracture aperture $(e)$ versus water pressure $(P)$ in the rock masses is presented in Fig. 8, which can be approximated with a constant in Phase I and simplified with a linear relationship in Phase II. Thus, $\left(P, e_{0}\right)$ is considered an important point that distinguishes flow phases, i.e., initial phases when $P$ is lower than $P_{c}$, and hydraulic-dilation phase when $P$ is higher than $P_{c}$. The two phases represent changes in the geometric characteristics of the fractures.

\section{Conclusions}

This work examines the hydraulic properties of natural sedimentary rocks in underground excavations between a deep tunnel and aquifers by using HPPTs, which have an important role for assessing the risk of water inrush. The following conclusions can be drawn from the presented results.

The results of the HPPTs indicate that mudstone and sandstone are compact materials with low permeability. The hydraulic conductivity varies with changes in the water pressure. High water pressure can result in several-fold increases in rock hydraulic conductivity. It is concluded that the hydraulic conductivity $(k)$ versus water pressure $(P)$ distribution phase is characterized by two key points ( $\mathrm{S}_{0}$ and $\left.\mathrm{S}_{\mathrm{s}}\right)$, i.e., the initial flow phase, initiation of flow communication phase, and non-steady state flow phase, thus representing the gradual evolution of rock permeability.

The flow rate $(Q)$ increases linearly with injection pressure $(P)$ until the fracturing threshold has been exceeded. Two distinct regimes of flow (Phases I and II) are proposed in accordance with the characteristics of the $P-Q$ plots obtained from the HPPTs. A linear relationship between the flow rate and pressure in Phase I can be used to identify the beginning of the Darcy flow, and thus initial estimations of hydraulic conductivity may be carried out based on regression analysis. Fracture dilation and hydraulic fracturing can both contribute to changes 
in the flow pattern as the injection pressure increases up to the critical pressure $(P)$.

The evolution of fracture apertures in rocks induced by water injection can be divided into two phases based on the critical point, i.e., the initial phase and hydraulic dilation phase, which represent changes in the fracture characteristics. A conceptual model of fracture aperture versus water pressure in the fractured rocks can be examined in future studies.

\section{Acknowledgements}

The authors gratefully acknowledge financial support from the National Natural Science Foundation of China (41702326), the National Postdoctoral Program for Innovative Talents (BX201700113), the China Postdoctoral Science Foundation (2017M620205), the Natural Science Foundation of Jiangxi Province (20171BAB206022), the State Key Laboratory for GeoMechanics and Deep Underground Engineering, China University of Mining and Technology (SKLGDUEK1703), and the Technology Project Founded by the Education Department of Jiangxi Province (GJJ160675).

\section{Conflict of Interest}

The authors declare no conflict of interest.

\section{References}

1. MIAO X.X., QIAN M.G. Research on the green mining of coal resources in China: current status and future prospects. J. Min. Saf. Eng. 26 (1), 1, 2009.

2. MA D., REZANIA M., YU H.S., BAI H.B. Variations of hydraulic properties of granular sandstones during water inrush: Effect of small particle migration. Eng. Geol. 217, 61, 2017.

3. MENG Z.P., LI G.Q., XIE X.T. A geological assessment method of floor water inrush and its application. Eng. Geol. 143-144, 51, 2012.

4. HUANG Z., JIANG Z.Q., ZHU S.Y., QIAN Z.W., CAO D.T. Characterizing the hydraulic conductivity of rock formations between deep coal and aquifers using injection tests. Int. J. Rock. Mech. Min. Sci. 71, 12, 2014.

5. WANG T.T., ZHAN S.S., CHEN C.H., SU W.C. Characterizing fractures to mitigate inrush of water into a shaft using hydrogeological approaches. Tunn. Undergr. Sp. Tech. 61, 205, 2017.

6. BUKOWSKI P. Water hazard assessment in active shafts in upper Silesian coal basin mines. Mine. Water. Environ. 30, 302, 2011.

7. ZAREI H.R., UROMEIHY A., SHARIFZADEH M. Evaluation of high local groundwater inflow to a rock tunnel by characterization of geological features. Tunn. Undergr. Sp. Tech. 26, 364, 2011.

8. Hödl R., Höllrigl M. Pummersdorfer Tunnel-water conditions in the shallow tunnel. Geomech. Tunnel. 7 (6), 664, 2014.
9. LI L., LEI T., LI S., ZHANG Q., XU Z., SHI S., ZHOU Z. Risk assessment of water inrush in karst tunnels and software development. Arab. J. Geosci. 8, 1843, 2014.

10. LI S.C., ZHOU Z.Q., LI L.P., LIN P., XU Z.H., SHI S.S. A new quantitative method for risk assessment of geological disasters in underground engineering: Attribute Interval Evaluation Theory (AIET). Tunn. Undergr. Sp. Tech. 53, 128, 2016

11. FARHADIAN H., KATIBEH H., HUGGENBERGER P. Empirical model for estimating groundwater flow into tunnel in discontinuous rock masses. Environ. Earth. Sci. 75 (6), 1, 2016.

12. WANG Y., YIN X., GENG F., JING H., SU H., LIU R. Risk Assessment of Water Inrush in Karst Tunnels Based on the Effcacy Coeffcient Method. Pol. J. Stud. 26 (4), 1765, 2017.

13. WANG Y., MENG F., GENG F., JING H., ZHAO N. Investigating Water Permeation through the soil-rock Mixture in Underground Engineering. Pol. J. Stud. 26 (4), 1777, 2017.

14. ZHU W.C., WEI C.H. Numerical simulation on mininginduced water inrushes related to geologic structures using a damage-based hydromechanical model. Environ. Earth. Sci. 62, 43, 2011.

15. LI L.P., TU W.F., SHI S.S., CHEN J.X., ZHANG Y.H. Mechanism of water inrush in tunnel construction in karst area. Geomat. Nat. Haz. Risk. 7 (S1), 35, 2016.

16. WANG Y., YANG W., LI M., LIU X. Risk assessment of floor water inrush in coal mines based on secondary fuzzy comprehensive evaluation. Int. J. Rock. Mech. Min. Sci. 52 (6), 50, 2012.

17. BAI H.B., MA D., CHEN Z.Q. Mechanical behavior of groundwater seepage in karst collapse pillars. Eng. Geol. 164, 101, 2013.

18. MA D., BAI H.B., CHEN Z.Q., PU H. Effect of Particle Mixture on Seepage Properties of Crushed Mudstones. Transp. Porous. Media. 108 (2), 257, 2015.

19. ANGUlO B., MORALES T., URIARTE I.A. Hydraulic conductivity characterization of a karst recharge area using water injection test and electrical resistivity logging. Eng. Geol. 117, 90, 2011.

20. HUANG Z., JIANG Z.Q., ZHU S.Y., WU X.S., YANG L.N., GUANG Y.Z. Influence of structure and water pressure on the hydraulic conductivity of the rock mass around underground excavations. Eng. Geol. 202, 74, 2016.

21. MENG Z.P., SHI X.C., LI G.Q. Deformation, failure and permeability of coal-bearing strata during longwall mining. Eng. Geol. 208, 69, 2016.

22. XIE H.P., GAO F., JU Y. Research and development of rock mechanics in deep ground engineering. Chin. J. Rock. Mech. Eng. 34 (11), 2161, 2015.

23. NEUMAN S.P. Trends, prospects and challenges in quantifying flow and transport through fractured rocks. Hydrogel. J. 13 (1), 124, 2005.

24. HAMM S.Y., KIM M., CHENG J.Y., KIM J.Y., SON M., KiIM T.W. Relationship between hydraulic conductivity and fracture properties estimated from packer test and borehole data in a fracture granite. Eng. Geol. 92 (1), 73, 2007.

25. CHEN Y.F., HU S.H., HU R., ZHOU C.B. Estimating hydraulic conductivity of fractured rocks from highpressure packer tests with Izbbash's law-based empirical model. Water. Resour. Res. 51, 2096, 2015.

26. GUGLIELMI Y., CAPPA F., LANCON H., JANOWCZYK J.B., RUTQVIST J., TSANG C. F., WANG J.S.Y. ISRM suggested method for step-rate injection method for 
fracture in-situ properties (SIMFIP): using a 3-components borehole deformation sensor. Rock. Mech. Rock. Eng. 47, 303, 2014.

27. DERODE B., CAPPA F., GUGLIELMI Y., RUTQVIST J. Coupled seismo-hydromechanical monitoring of inelastic effects on injection-induced fracture permeability. Int. J. Rock. Mech. Min. Sci. 61 (10), 266, 2015.

28. LE BORGNE T., BOUR O., PAILLE F.L., CAUDAL J. P. Assessment of preferential flow path connectivity and hydraulic properties at single-borehole and crossborehole scales in a fractured aquifer. J. Hydrol. 328, 347, 2006.

29. DERODE B., CAPPA F., GUGLIELMI Y., RUTQVIST J. Coupled seismo-hydromechanical monitoring of inelastic effects on injection-induced fracture permeability. Int. J. Rock. Mech. Min. Sci. 61 (10), 266, 2013.

30. CHEN Y.F., LIU M.M., HU S.H., ZHOU C.B. Non-Darcy's law-based analytical models for data interpretation of highpressure packer tests in fractured rocks. Eng. Geol. 199, 91, 2015.

31. ZHANG X.M., JIANG Z.M., FENG S.R., CHENG S.D. Study on the determination of permeability coefficient of fractured rock mass under pressure test condition. J. Hydroelectric. Eng., 30 (1), 155, 2011.

32. LIANG D.X., JIANG Z.Q., GUAN Y.Z. Field Research: Measuring Water Pressure Resistance in a Fault-Induced Fracture Zone. Mine Water Environ. 34 (3), 320, 2015.

33. HUANG Z., JIANG Z., TANG X., WU X., GUO D., YUE Z. In situ Measurement of Hydraulic Properties of the Fractured Zone of Coal Mines. Rock Mech. Rock Eng. 49 (2), 603, 2016

34. WANG H.L., XU W.Y., SHAO J.F., SKOCZYLAS F. The gas permeability properties of low-permeability rock in the process of triaxial compression test. Mater. Lett. 116, 386, 2014.

35. QUINN P.M., PARKER B.L., CHERRY J.A. Using constant head step tests to determine hydraulic apertures in fractured rock. J. Contam. Hydrol. 126 (1), 85, 2011.

36. QUINN P.M., CHEERY J.A., PARKER B.L. Quantification of non-Darcian flow observed during packer testing in fractured sedimentary rock. Water. Resour. Res. 47 (9), 178, 2011.

37. RUTQVIST J. Fractured rock stress-permeability relationships form in situ data and effects of temperature and chemical-mechanical couplings. Geofluids, 15 (1-2), 48, 2014.

38. RANJITH P.G., VIETE D.R. Applicability of the 'cubic law' for non-Darcian fracture flow. J. Petrol. Sci. Eng. 78, 321, 2011.
39. JIANG Z.M., FU S., LI S.G., HU D.K., FENG S.R. High pressure permeability test on hydraulic tunnel with steep obliquity faults under high pressure. Chin. J. Rock. Mech. Eng. 26 (11), 2318, 2007.

40. HUANG Z., JIANG Z.Q., SU Q., CAO D.T., WANG Y.J., ZHANG D. High-pressure water injection tests on permeability of deep rock mass under tunnels. Chin. J. Geotech. Eng. 36 (8), 1535, 2014.

41. HUANG Z., JIANG Z., FU J., CAO D. Experimental measurement on the hydraulic conductivity of deep lowpermeability rock. Arab. J. Geosci. 8, 5389, 2015.

42. OLSSON R., BARTON N. An improved model for hydromechanical coupling during shearing of rock joints. Int. J. Rock. Mech. Min. Sci. 38, 317, 2011.

43. OSIPTSOV A.A. Fluid Mechanics of Hydraulic Fracturing: a Review. J. Petrol. Sci. Eng. 156, 513, 2017.

44. BLUNSCHI J., ERTEKIN T., WANG J. Hydraulic fracturing mechanisms in coal: a review. Int. J. Oil Gas Coal Tech. 14 (3), 247, 2017.

45. SUPPACHOKNIRUN T., TUTUNCUN A.N. Hydraulic Fracturing and Production Optimization in Eagle Ford Shale Using Coupled Geomechanics and Fluid Flow Model. Rock Mech. Rock Eng. 50 (12), 3361, 2017.

46. SOULEY M., LOPEZ P., BOULON M., THORAVAL A. Experimental hydromechanical characterization and numerical modelling of a fractured and porous sandstone. Rock. Mech. Rock. Eng. 48 (3), 1143, 2015.

47. MAO R.B., FENG Z.J., LIU Z.H., ZHAO Y.S. Laboratory hydraulic fracturing test on large-scale pre-cracked granite specimens. J. Nat. Gas Sci. Eng. 44, 278, 2017.

48. TAN P., JIN Y., HAN K., HOU B., CHEN M., GUO X.F., GAO J. Analysis of hydraulic fracture initiation and vertical propagation behavior in laminated shale formation $[\mathrm{J}]$. Fuel, 206, 482, 2017.

49. LIANOS E.M., JEFFREY R.G., HILLIS R., ZHANG X. Hyaraulic fracture propagation through an orthogonal discontinuty: a laboratory, analytical and numerical study. Rock Mech. Rock Eng. 50 (8), 2101, 2017.

50. WANG W., TALEGHANI A.D. Impact of hydraulic fracturing on cement sheath integrity; A modelling approach. J. Nat. Gas Sci. Eng. 44, 265, 2017.

51. WANG L., CARDENAS M.B., SLOTTKE D.T., KETCHAM R.A., SHARP JR J.M. Modification of the local cubic law of fracture flow for weak inertia, tortuosity, and roughness. Water. Resour. Res. 51, 2064, 2015.

52. JAMISON W., AZAD A. The hydraulic fracture-natural fracture network configuration in shale reservoirs: Geoligical limiting factors. J. Petrol. Sci. Eng. 159, 205, 2017. 
